\title{
歯槽部皮質骨骨切り術を併用した歯列矯正治療の臨床的検討
}

\author{
中美俊大.石井保 雄 ${ }^{*} \cdot$ 林 解平*.都築 雅弘* \\ 玉 井 学*.小笠原利行*.木 村 博 人** $^{* *}$
}

\section{A clinical study of orthodontic treatment with alveolar corticotomy}

\author{
Toshihiro NAKAMI $\cdot$ Yasuo IsHII $\cdot$ Kaihei HaYASHI ${ }^{*} \cdot$ Masahiro TuzUKI* \\ Manabu Tamai* $\cdot$ Toshiyuki Ogasawara**Hiroto Kimura**
}

\begin{abstract}
To shorten the treatment period and to prevent relapse, Köle recommends that corticotomy be performed in adults who undergo orthodontic treatment and in persons in whom such treatment is delayed. However, Köle's method has disadvantages such as gingival recession and resorption of the alveolar crest, because it entails cutting the alveolar crest with a bur. To avoid these disadvantages, we modified Köle's method and cut the alveolar crest with only a chisel.

This modified procedure was performed in 19 patients undergoing preoperative orthodontic treatment for maxillofacial deformity and in 5 patients receiving adjunctive treatment for conventional orthodontic therapy. With this procedure, the duration of tooth movement was shortened and no complications, including recession of the interdental papilla, occurred during the course of treatment. The esthetic outcome was also satisfactory.
\end{abstract}

Key words: modified Köle's method (改良 Köle 法), alveolar corticotomy（歯槽部皮質骨骨切り 術), orthodontic treatment（歯列矯正治療）

緒言

近年, 審美的あるいは機能的要求により歯列矯正治 療を希望し来院する患者が増加している。しかし，患 者の通院期間あるいは経済的制約により，矯正治療を 断念せざるを得ない患者も少なくない。通院期間を問 題とする患者に対して, 短期間で満足のいく結果を得 るには, 侵襲が少なく，歯牙移動量の大きい治療法が

六ヶ所村立尾駮診療所歯科

*福井医科大学歯科口腔外科学教室

(主任: 石井保雄教授)

**弘前大学医学部㐘科口腔外科学教室

(主任 : 木村博人教授)

Department of Dentistry, Rokkasyo Village's Obuti Clinic

* Department of Dentistry and Oral Surgery, Fukui Medical School (Chief: Prof. Yasuo Ishii)

** Department of Dentistry and Oral Surgery, Hirosaki University School of Medicine (Chief: Prof. Hiroto Kimura)

受付口: 平成 6 年 12 月 12 口
望まれる. Köle ${ }^{1)}$ は矯正治療期間の短縮および後戻 り防止の観点から歯牙移動の抵抗となっている歯槽部 皮質骨を切削する歯槽部皮質骨骨切り術（alveolar corticotomy）を報告している. しかし，この方法は バーを用いて歯槽中隔上縁を切削するために歯間乳頭 部の退縮と歯槽中隔上縁部の吸収を引き起こす欠点が ある。そこで, 今回筆者らは, Köle 法を一部改良し歯 列不正患者に対し適用したので, 術式の紹介と術後経 過について臨床的に検討するとともに, 若干の文献的 考察を加え報告する。

\section{対象症例の内訳}

対象症例は 1984 年 7 月より 1989 年 12 月までの 5 年 6 只間に福井医科大学附属病院歯科口腔外科で顎矯 正手術の術前矯正および一般歯列矯正治療時に皮質骨 骨切り術を併用した 24 例である. 24 症例中, 顎変形 症の術前矯正治療時に併用した症例は男性 5 例，女性 14 例の計 19 例，歯列矯正に併用した症例は男性 1 例, 女性 4 例の計 5 例であった。これら 24 例の年齢範囲 
表 1 皮質骨骨切り術実施症例

\begin{tabular}{r|rc|cc}
\hline & \multicolumn{2}{|c|}{ 術前歯列矯正の補助 } & \multicolumn{2}{c}{ 一般歯列矯正の補助 } \\
年齢 (歳) & 男 & 女 & 男 & 女 \\
\hline$\sim 18$ & - & 6 & - & 1 \\
$19 \sim 20$ & 2 & 2 & - & - \\
$21 \sim 22$ & 1 & 3 & - & - \\
$23 \sim 24$ & - & 2 & 1 & - \\
$24 \sim$ & 2 & 1 & - & 3 \\
\hline 合 計 & 5 & 14 & 1 & 4 \\
\hline
\end{tabular}
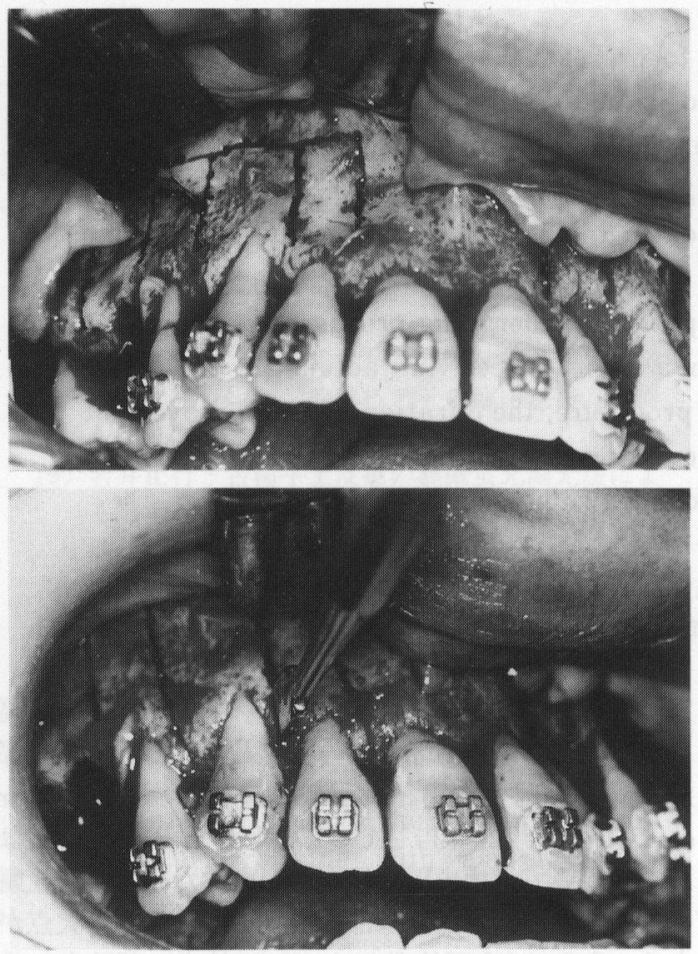

写真 1 石井式改良皮質骨骨切り術の術中所見

上段：歯槽中隔上縁部を残し，歯の近遠心および根尖部 の皮質骨切除終了時.

下段：歯槽中隔上縁部に向かってチゼルにて割を入れて いる状態

は 16 歳から 38 歳までで, その平均年齢は 22 歳であつ た。また性比では男性 1 に対し女性 3 の割合で女性患 者が大多数を占めた（表 1 ）。これらの症例に対し，以 下に述べる術式に従って皮質骨骨切り術を併用した矯 正治療を施行し，矯正治療期間について検討した。
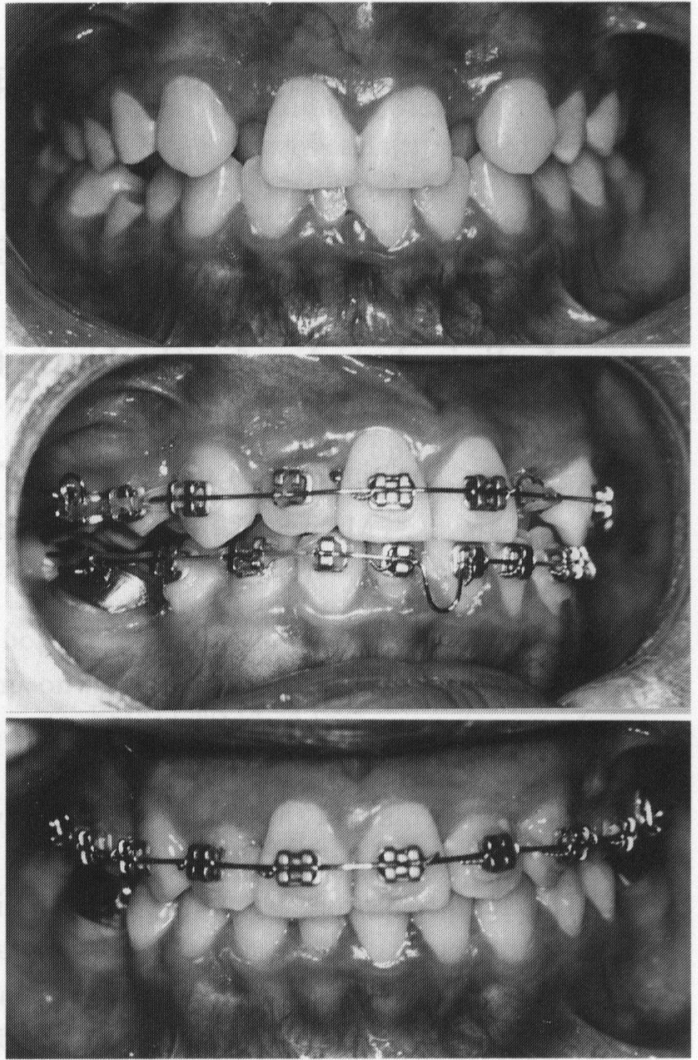

写真 2 歯列矯正に皮質骨骨切り術を併用した症例 上段 : 術前所見.

中段 : 術後 3 か月，歯牙移動中の所見.

下段：術後 6 か月, 歯牙移動終了時の所見. 歯間乳頭部 の退縮は認められない.

術

式

従来の Köle 法に準じ, 局所麻酔下に歯槽中隔部を 歯軸と平行に縦方向の皮質骨骨切りを行い,さらに根 尖より $5 \mathrm{~mm}$ 以上離れた位置で横方向の皮質骨骨切 りを施行した。この際, 術後の歯間乳頭部の退縮およ び歯槽中隔上縁部の吸収を避け歯牙移動を容易にする ため, Köle 法における歯槽中隔上縁部までのバーに よる切削を避け，チゼルで歯槽中隔上縁部に割を入れ る方法を用いた（写真 1 ).

矯正装置は骨切り術直後に装着し, 動的移動を開始 した. 矯正力は術後 $2 \sim 3$ か月以内までは, 顎整形力 に準じ通常の 2 倍以上の力 $(300 \sim 1000 \mathrm{~g})$ をかけ目的 部位まで移動させた. 歯列側方拡大を目的とする症例 では急速拡大装置（エクスパンションスクリュー）を 併用し，歯列矯正を目的とする症例では，ダイレクト ボンディング法を用いた（写真 2 ). 
表 2 皮質骨骨切り術を実施した部位別歯数

\begin{tabular}{c|ccccccc}
\hline 歯 数 & 25 & 28 & 24 & 9 & 13 & 8 & 5 \\
\hline 上顎 & $\frac{1}{2}$ & $\frac{2}{3}$ & $\frac{3}{2}$ & $\frac{4}{3}$ & $\frac{5}{4}$ & $\frac{6}{5}$ & $\frac{7}{5}$ \\
\hline 下顎 & $\overline{1}$ & $\frac{-}{2}$ & $\overline{3}$ & $\overline{7}$ \\
\hline 歯 数 & 2 & 2 & 3 & 3 & 2 & - & - \\
\hline
\end{tabular}

\section{経過ならびに結果}

\section{1. 施行部位および施行状況}

24 症例に扔ける皮質骨骨切り術施行部位別歯数は, 上顎では前歯部 77 歯, 小臼歯部 22 歯, 大臼歯部 13 歯 であり,下顎は前歯部 7 歯, 小臼歯部 5 歯であった。 また, 24 例中入院で施行した症例は 17 例, 外来で施 行した症例は 7 例であった（表 2 ).

\section{2. 平均矯正治療期間}

24 症例に皮質骨骨切り術施行後, 矯正治療終了まで の矯正治療期間を調查した。その結果，顎矯正手術の 術前矯正治療例 19 例のうち側方拡大装置のみを装着 したものは 4 例で, 矯正治療期間の平均は 39 日であ り，歯列矯正のみを施行したものは 6 例で矯正治療期 間は平均 102 日，両者を併用したものは 9 例で矯正治 療期間は平均 101 日であった。これら術前矯正治療の 19 例の平均矯正治療期間は 88 口であった。また,一 般歯列矯正のみに施行した症例は 5 例で, その平均矯 正治療期間は 145 口であった（表 3 ).

\section{3 . 皮質骨骨切り術に伴う併発症の有無}

矯正期間中に歯髄炎，歯肉腫脹などの異常を生じた 症例は全くなかった。また，歯間乳頭部歯肉の異常な 退縮も認められず，X 線学的所見でも歯根吸収および 歯槽中隔上縁部の著明な骨吸収は認められなかった。

\section{考察}

近年，矯正治療を希望する患者が増加しているが， 社会的あるいは経済的制約により，治療を断念する患 者も少なくない。このような患者に対し，短期間で満 足のいく結果を得るには, 歯を早く動かせる治療方法 が望まれている，㐘に矯正力を作用させた場合，矯正 力に対する抵抗因子の 1 つは被移動歯周囲の皮質骨と されている.

1959 年, Köle ${ }^{1)}$ は皮質骨の切離により, 歯牙の移 動が容易となり，矯正期間の短縮ができるとし，前歯 の唇舌的移動, 過蓋咬合の改善, 犬歯, 小臼歯の遠心 移動，前歯の整直，歯間空隙の閉鎖，臼歯部の側方拡 大などに用い成功した㫌例を報告した。また，皮質骨
表 3 皮質骨骨切り術施行後の平均矯正治療期間

\begin{tabular}{ll|c|c}
\hline \multicolumn{2}{c|}{ 施行目的, 内容 } & 症例数 & $\begin{array}{c}\text { 平均矯正治療 } \\
\text { 期間 }(\text { 日 })\end{array}$ \\
\hline 拡大 & $\rightarrow$ 顎矯正手術 & 4 & 39 \\
歯列矯正 $\rightarrow$ 顎矯正手術 & 6 & 102 \\
拡大十歯列矯正 $\rightarrow$ 顎矯正手術 & 9 & 101 \\
歯列矯正単独 & 5 & 145 \\
\hline
\end{tabular}

骨切り術施行後の矯正期間についても $6 \sim 12$ 週間で 矯正の目的を達成することが可能であると述べている. 皮質骨骨切り術後の急速な歯体移動の為害性につい て, Yoshikawa ${ }^{2)}$ らは, 骨の切離は表面皮質骨に限 局され，骨片は骨髄によって保持されるため，骨や歯 牙への血管および神経を傷つけることは少ないと述べ ている. 中西 ${ }^{3)}$, 伊東ら ${ }^{4)}$ は成犬で本法を施行後, 急 速な拡大や強い矯正力をかけた後の骨改造について組 織学的に検討し, 本法の有用性を明らかにした。

また, 骨切り線相当部の治瘉過程に関して, 西田ら ${ }^{5)}$ はX 線写真上で経過観察し, 骨切り線が消失するま でに術後少なくとも3 か月は必要であると報告し，こ れは Köle ${ }^{1)}$ のいう歯の動摇もなく短期間に移動がで きる期間と一致している. 従って本法施行後の効果的 な移動期間内に適度の矯正力を加えた場合, セグメン トの移動がみられ歯体移動が容易になるものと考えら れる.

以上のような研究に裏付けられ, 本法は臨床的にも 多数応用されてきた ${ }^{5-7)}$. 特に, エクスパンション スクリューを用いた歯列の側方拡大を併用する方法は, 歯を早く移動して治療期間を短縮でき, また術後の後 戻りが少なく, 成人にも適用できる最も効果的な方法 であるとされている ${ }^{7)}$. 成長期における一般歯列矯正 の霜牙移動で, 局所的な骨代謝機能による形態的変化 は成長, モデリングおよびリモデリングであり，成長 後の本法を併用した歯列矯正の骨形態変化は修正とリ モデリングによると考えられる. 本法による歯槽部皮 質骨の切離は, 歯牙移動の抵抗因子を排除する一方, 成長後の歯列矯正で強力な顎整形力を加えても応力分 布および局所の骨代謝機能による短期間の形態的変化 に十分対忘する結果であると思われる.すなわち歯に 加わる整形力は上顎では, 歯牙 $\rightarrow$ 歯根膜 $\rightarrow$ 歯槽内壁線 維骨 $\rightarrow$ 歯槽部海綿骨 $\rightarrow$ 歯槽部皮質骨 $\rightarrow$ 骨体内海綿骨 $\rightarrow$ 上顎骨縫合部の順で伝播され，その拡散は縫合部で終 わる.これに対して下顎では, 歯牙から骨体内海綿骨 までは同様であるが整形力の拡散は下顎骨下縁で終わ るとされている ${ }^{8)}$. 従って, 整形力の伝播, 拡散は皮 質骨骨切り術によって皮質骨の部位で遮断されるため, 海綿骨に大きな力として働く ${ }^{9)}$ が, 海綿骨の骨代謝 
速度は皮質骨の約 8 倍以上 ${ }^{10)}$ とされており, 整形力 に対応して歯の移動量も大きく移動速度も早いと思わ れる。

一方, 本法は歯槽中隔上縁部をバーで切削するため, 術後の歯肉退縮や歯槽骨の吸収を伴うこと, 隣接歯間 が近接している症例では歯根を損傷することなどが最 大の欠点とされている ${ }^{11)}$.このような欠点に対して筆 者らは，歯槽骨頂までのバーによる骨切りを避け，歯 槽中隔部についてはチゼルを用いて歯槽中隔上,縁部に 割のみを入れる術式に改良した。筆者らの方法では歯 牙移動後の歯間乳頭部歯肉の退縮を起こしにくく, 隣 接㐘間が近接している症例でも，本法を施行すること ができた。

また，皮質骨骨切り術施行後の矯正治療期間につい て分析した結果は, 顎矯正手術の術前矯正に本法を併 用しない場合の治療期間は 1 年前後を要するという従 来の報告 ${ }^{12}$ １3）と比較して, 明らかに治療期閒の短縮 を示すものであった. 本法の適忍年齢について, Köle ${ }^{1)}$ は 16 歳以上の患者はすべて対象となると述べている が, 筆者らは 16 歳から 38 歳までの 24 症例に適用し, いずれも矯正治療期間は短縮し，臨床上満足すべき結 果が得られた。

\section{結語}

成人の歯列矯正および術前矯正の矯正治療期間の短 縮化, 後戻り防止のため, 歯槽部皮質骨骨切り術を併 用する Köle 法は, 歯槽中隔上縁部の切削により歯肉 退縮や歯槽中隔部の骨吸収が起こる。そこで筆者らは, 歯槽頂部をチゼルを用いて分割する術式を考案し，24 症例に本法を施行した。

その結果, 術後の歯肉退縮や歯槽中隔部の骨吸収は 認められず，歯間乳頭部の審美的な保全が得られた。 また，矯正治療期間の大幅な短縮が得られ，治療中， 歯牙および歯周組織における偶発怔は特に認められな かった.

本論文の要旨は, 第 16 回日本口腔外科学会北日本地方 会 (平成 2 年 2 月 弘前) において発表した。

\section{引用 文 献}

1) Köle, H.: Surgical operations on the alveolar ridge to correct occlusal abnormalities. Oral Surg 12: 515-529 1959.

2) Yoshikawa, Y., Deguchi, T., et al.: Pulpal and radicular changes following maxillary subapical corticotomy. Endod Dent Traumatol 8:245-247 1992.

3）中西秀男: Osteotomy および Corticotomy を併用した実験的歯牙移動の研究. 歯科学報 82: 219-252 1982 .

4）伊東隆三, 中島 誠, 他: Corticotomy を併 用した歯牙移動に関する実験的研究. 日矯歯誌 40: 92-105 1981 .

5）西田光男, 飯塚忠彦, 他：Köle 法による corticotomy の臨床的検討. 日П外誌 32: 318-325 1986.

6）塩田重利, 橋本賢二: 唇顎口蓋裂形成後におけ る顎・顔面・回腔領域の変形に対する修復手術. 形成外科 20: 171-183 1977.

7）寺田員人, 向阪康彦, 他：下顎枝矢状分割法に おける上下顎歯列弓幅径の調和の重要性につい て一術前矯正治療における expansion screw と corticotomy の併用例-- 日矯㐘誌 46: 1071201987.

8）堤 定美：上下顎骨に加わる力と歪みについて. オーラルマキシロフェイシャル インプラント $3: 197-2061989$.

9）吉川仁育：顎整形力による、頿骨後方移動時の Corticotomy の効果に関する研究. 松本歯学 13: 292-320 1987.

10) Bauer, G.C.H.: Kinetics of bone diseases. Bone Mineral Dynamics 27: 489-507 1964.

11) Bell, W.H. and Levy, B.M.: Revascularization and bone healing after maxillary corticotomies. J Oral Surg 30: 640-648 1972.

12）徳田信春, 大竹秀明, 他：下碩枝矢状分割法に おける術前矯正治療とその䦗題点. 顎変形誌 4 : 39-41 1985.

13）迫田隅男, 福原博 - 他：当科の顎矯正手術に 関する臨床的検討. 硕変形誌 2 : 125-131 1992. 